\title{
Openbaarmaking van belastinginligting in die finansiële verslae van maatskappye: Vereistes, riglyne en mate van voldoening
}

\author{
M Stiglingh \\ Departement Belasting \\ Universiteit van Pretoria
}

\author{
JFM Kotzé \\ Universiteit van Pretoria
}

\begin{abstract}
The purpose of this study was to determine the requirements and guidelines for the disclosure of taxation information in the financial reports of South African companies in order to determine the extent to which leading South African companies comply with these requirements and guidelines.

It was determined that there are comprehensive requirements and guidelines in respect of the disclosure of taxation information in the financial reports of South African companies. These requirements and guidelines are regulated by the Companies Act, No. 61 of 1973, as well as the statements of Generally Accepted Accounting Practice that are issued by the South African Institute of Chartered Accountants.

The analyses undertaken of the financial statements of the selected companies indicate that leading companies in South Africa comply to a large extent with the requirements and guidelines for the disclosure of taxation information in financial reports.
\end{abstract}

\section{Key words}

Disclosure of current taxation

Disclosure of deferred taxation

Disclosure of taxation in cash-flow statements

Disclosure of taxation in notes to financial statements

Contact the editor if you require the article in English.

Meditari Accountancy Research Vol. 102002 : 187-208 


\section{Agtergrond en uiteensetting}

\subsection{Inleiding}

Die kerndoel van die Rekeningkunde is kommunikasie, dit wil sê die verskaffing van inligting aan alle partye wat belang by die bedrywighede van 'n bepaalde onderneming het (Faul, Pistorius, Van Vuuren and De Beer 1994:7). Hedendaags is daar ' $n$ groot getal sodanige belanghebbende partye, insluitende die eienaars van die onderneming, wat finansiële inligting vereis oor hoe die besigheid bestuur word, en die staat, wat die finansiële resultate van die onderneming as grondslag vir die heffing van belasting gebruik (Flynn, Koornhoff and Bezuidenhout 1987:8). Die behoeftes van elkeen van hierdie groepe ten opsigte van finansiële verslae verskil. Om aan die behoeftes van die onderskeie gebruikers van finansiële verslae te voldoen, word regulasies en riglyne vir die openbaarmaking van inligting in finansiële verslae gestel (RE 000: Voorwoord). Algemeen aanvaarde rekeningkundige praktyk het ten doel om te verseker dat finansiële verslae 'n redelike of billike weergawe van 'n entiteit se prestasie vir 'n bepaalde tydperk en die finansiële stand op 'n bepaalde tydstip verskaf, asook om vergelykbaarheid tussen die finansiële verslae van verskillende entiteite te vergemaklik (Cilliers, Mans, Grobbelaar, Stegmann, Van Schalkwyk and Wesson 1999:43).

In Littleton and Zimmerman (1962:15) word die volgende stelling gebruik om die waarde van openbaarmaking te verduidelik:

"What we cannot know about the future will not be known no matter how hard the prophets stare into their assorted crystals; but what can be known, and it is on the skeptic's own showing far from negligible, can be rationally used to carry us into the future with some understanding of what we are doing and of the resources on which we can draw to meet its risks and surprises, whatever they may prove to be, with intelligence and resolution."

In 'n perfekte wêreld sal die syfers in finansiële verslae voldoende wees om aan die gebruikers daarvan alles te vertel wat hulle oor die betrokke onderneming moet weet. Syfers is presies, definieerbaar en meetbaar, maar in die praktyk het gebruikers ook woorde nodig om die volle verhaal van 'n besigheid te begryp. Die doel met die verskaffing van aantekeninge tot finansiële verslae is om die volle verhaal van die entiteit te vertel (Wells 2001:47).

Finansiële verslagdoening ontwikkel in pas met die groei in kapitaalmarkte (Lin and Wang 2001:263). Met die ontwikkeling van aandelemarkte het hierdie medium sedert 1920 'n hoofbron vir die insameling van kontant of beleggings geword. Hierdie verandering in die besigheidsomgewing het veroorsaak dat daar 'n verdeling gekom het tussen die eienaarskap en die bestuur van ondernemings. Professionele bestuurspanne bestuur ondernemings met hulpbronne wat deur die eienaars (aandeelhouers) aan die bestuur toevertrou word (Lin and Wang 2001:263). 'n Kontraktuele ooreenkoms het tussen die aandeelhouers en die bestuur ontwikkel. 
As gevolg van die ongelykmatigheid van inligting, mag bestuur, wat toegang tot die inligting van die daaglikse bedrywighede van die onderneming het, probeer om hulle eie belang te bevorder, selfs ten koste van die eienaars van die onderneming (Fama 1970:29). Eienaars of aandeelhouers sal egter poog om wangedrag deur bestuur te beperk en daarom word verantwoording en verslagdoening as 'n meganisme gebruik om die kontraktuele vordering tussen die bestuur en die eienaars te moniteer (Watts and Zimmerman 1986:76).

Volgens die agentskapsteorie, sal bestuur, wat kontraktueel tot die behoorlike bestuur van die onderneming verbind is, gemotiveer wees om die verwagte en vrywillige openbaarmaking van inligting te doen om sodoende die agentskapskoste wat hulle moet dra, te verminder (Holthausen and Leftwich 1983:34). Daarom word korporatiewe rapportering reeds vir 'n geruime tyd gebruik as 'n primêre middel vir (huidige en toekomstige) eienaars om te bepaal wat die aanspreeklikheid van bestuur is en ook om rasionele beleggingsbesluite te kan neem (Holthausen and Leftwich 1983:35).

Volgens die tweede King-verslag (2002:147) hou die aanvaarding van 'n filosofie van openbaarmaking van inligting in finansiële verslae 'n aantal voordele in: Eerstens het dit 'n krimpende effek, dit wil sê wanneer bepaalde inligting openbaar word, insluitend die ontvangs van voordele, het dit gereeld die effek van 'n beperking op die aanvaarding van 'n sodanige beleid. In hierdie geval sal dit lei tot 'n beperking van wanpraktyke of buitensporige vergoeding vir die uitvoerende bestuurslede (King 2002:147). Die tweede voordeel van openbaarmaking is dat dit wangedrag en swak prestasie uitwys. Daardeur bemagtig dit die slagoffers om bewus te wees van die pligsversuim sodat toepaslike regstellende aksie geneem kan word (King 2002:147).

Die Maatskappywet vereis dat finansiële verslae van maatskappye, in ooreenstemming met algemeen aanvaarde rekeningkundige beleid, die stand van sake en die resultaat van die entiteit op 'n redelike wyse moet weergee (King 2002: 135). Regsopinies verkry in 1977 en 1987 het bevestig dat die Suid-Afrikaanse standpunte van algemeen aanvaarde rekeningkundige praktyk, soos deur die Rekeningkundige Praktykeraad goedgekeur, wel algemeen aanvaarde rekeningkundige praktyk verteenwoordig (King 2002:135).

Die belangrikheid van die openbaarmaking van finansiële inligting, asook die gebruik van finansiële verslae, is tydens die onlangse Enron-debakel beklemtoon. Die gebruikers van die finansiële verslae is mislei deurdat alle inligting wat vir 'n beleggingsbesluit benodig word nie aan hulle openbaar is nie. Lank nadat die stof oor die debakel gaan lê het, sal beleggers steeds staat maak op die finansiële verslae wat hulle so teleurgestel het (Byrnes 2002:36). In 'n verklaring deur die voorsitter van die SEC, mnr Pitt (2002:1), na die Enronvoorval, is gesê dat beleggers daarop geregtig is om te vertrou op die stelsel van openbaarmaking van inligting in finansiële verslae.

Soos alle ander inligting in die finansiële verslae, kan openbaarde inligting met betrekking tot, byvoorbeeld, belasting ook 'n effek hê op of 'n verskil maak 
aan die besluit wat die gebruiker van die finansiële state neem. Gedurende die afgelope dekade het baie ontwikkeling op alle gebiede van openbaarmaking plaasgevind (Marlton 2001:6) en die openbaarmaking van belastinginligting het nie agterweë gebly nie. Openbaarmaking van inligting met betrekking tot belasting word in algemeen aanvaarde rekeningkundige beleid (RE 102: § 83 92) en in die Maatskappywet (bylae $4 \S 16$, bylae $4 \S 42$ (d)) voorgeskryf.

\subsection{Omskrywing van die probleem}

Alhoewel regulasies en riglyne ingevolge algemeen aanvaarde rekeningkundige praktyk en die Maatskappywet daargestel word, is dit moontlik dat hierdie regulasies en riglyne nie konstant in die praktyk toegepas word nie. Dit kan daartoe aanleiding gee dat gebruikers van finansiële verslae nie voorsien word nie van die ideale inligting vir besluitneming ooreenkomstig die bedoeling van die regulasies en riglyne wat in algemeen aanvaarde rekeningkundige praktyk en die Maatskappywet uiteengesit word.

\subsection{Doelwit van die studie}

1.3.1 Die hoofdoelwit van die studie was om te bepaal wat die heersende vereistes en riglyne vir openbaarmaking van inligting met betrekking tot belasting in finansiële verslae is en tot watter mate top Suid-Afrikaanse maatskappye aan hierdie vereistes en riglyne voldoen.

\subsection{Hipotese}

Die verwagting was dat nie alle top maatskappye in Suid-Afrika aan die vereistes en regulasies vir die openbaarmaking van belastinginligting in finansiële verslae, soos in RE 102 en die Maatskappywet van 1973 voorgeskryf, voldoen nie.

\subsection{Afbakening van die omvang van die studie}

Hierdie ondersoek is beperk tot die openbaarmaking van belastinginligting in finansiële state soos deur RE 102 en die Maatskappywet vereis en het 'n ondersoek van die finansiële verslae van 'n aantal geselekteerde maatskappye behels. Verder is slegs aan die hoeveelheid van openbaarde inligting aandag geskenk en nie aan die kwalitatiewe aspekte van die openbaarde inligting nie. Die rekeningkundige hantering van belastingverskille, of die rekeningkundige teboekstelling daarvan, is nie ontleed nie. Die studie het slegs die top 200 maatskappye in Suid-Afrika betrek; derhalwe word gevolgtrekkings ook slegs ten opsigte van hierdie maatskappye gemaak.

\subsection{Strategie van die navorsing}

Hierdie ondersoek behels 'n studie van die literatuur oor die vereistes en riglyne vir die openbaarmaking van belastinginligting in finansiële verslae asook 'n 
empiriese studie om te bepaal in welke mate top maatskappye in Suid-Afrika aan hierdie vereistes en riglyne voldoen.

\section{Vereistes en riglyne vir openbaarmaking van belastinginligting}

\subsection{Inleiding}

Volgens Everingham en Kana (2000:1) is die volgende drie bronne die hoofbronne vir riglyne vir openbaarmaking in gepubliseerde finansiële verslae van Suid-Afrikaanse entiteite:

- Die Maatskappywet, No. 61 van 1973, en meer spesifiek bylae 4 van die Wet.

- Standpunte van algemeen aanvaarde rekeningkundige praktyk (die 100reeks) deur die Rekeningkundige Praktykeraad van die Suid-Afrikaanse Instituut van Geoktrooieerde Rekenmeesters goedgekeur; rekeningkundige riglyne (die 200-reeks) deur die Rekeningkundige Praktykeraad goedgekeur; rekeningkundige opinies (die 300-reeks) en Interpretasies van die AARP (die 400-reeks).

- Standpunte en interpretasies deur die Internasionale Rekeningkunde Standaardekomitee uitgereik. Aangesien hierdie aangeleentheid nie verpligte openbaarmaking vir entiteite tot gevolg het nie, word hierdie bron van openbaarmaking nie in hierdie studie oorweeg nie.

Wat betref die tweede bron wat hierbo genoem word, is dit belangrik om te let op die gesag wat elk van die reekse dra. Die 100-, 400- en 500-reekse is die verpligte openbaarmaking waaraan entiteite moet voldoen om aan algemeen aanvaarde rekeningkundige beleid te voldoen. Die 200- en 300-reekse behels riglyne en opinies. Entiteite is nie verplig om daaraan te voldoen nie om nakoming van algemeen aanvaarde rekeningkundige praktyk te verseker (SAIGR 2000:1). Die riglyne wat in RE 303 aangedui word, is egter ter wille van volledigheid in hierdie studie ingesluit.

Standpunt RE 102, oor Inkomstebelasting, het betrekking op belastings wat regstreeks op inkomste ingevolge die Suid-Afrikaanse Inkomstebelastingwet, No. 58 van 1962, soos gewysig gehef word of soortgelyke belastings van ander lande wat op inkomste uit buitelandse bronne gehef word. Dit het ten doel dat die toepaslike bedrag van belasting in die finansiële verslae van 'n onderneming getoon sal word (RE 102.01). Vir die doeleindes van hierdie ondersoek sal RE 102 (wat in Maart 1999 hersien is) gebruik word om die vereistes vir openbaarmaking te bepaal. Alhoewel hierdie standpunt deur RE 102 (hersien in April 2001) vervang is, is daar steeds van RE 102 (wat in Maart 1999 hersien is) gebruik gemaak, omdat geen een van die entiteite wat in die steekproef ingesluit is ' $n$ jaareinde het wat na die effektiewe datum van RE 102 (in April 2001 hersien) val nie. Verder was daar tydens die uitvoering van die ondersoek 
nie finansiële verslae beskikbaar wat aan RE 102 (in April 2001 hersien) onderhewig was nie. Die effektiewe datum van RE 102 (in Maart 1999 hersien) was 1 Julie 1999 en die effektiewe datum van RE 102 (in April 2001 hersien) is 1 Januarie 2001.

Vervolgens word ' $n$ uiteensetting gegee van die vereistes vir openbaarmaking van belastinginligting in finansiële verslae van maatskappye, met spesifieke verwysing na die vereistes vir openbaarmaking van inligting in die balansstaat, inkomstestaat, kontantvloeistaat en aantekeninge tot die finansiële verslae ingevolge bylae 4 van die Maatskappywet sowel as RE 102.

\subsection{Belastinginligting in die balansstaat}

Ingevolge RE 102.73 en bylae 4.16(c) van die Maatskappywet moet belastingbates en -laste afsonderlik van ander bates en laste van die maatskappy getoon word bylae 1: $\S 1.1$ ).

Verder bepaal RE 102.73 dat uitgestelde belastingbates en -laste van lopende belastingbates en -laste in die nota's tot die finansiële verslae onderskei moet word (bylae 1: $\S 1.2$ ). Indien die onderneming onderskei tussen lopende en nielopende bates en laste, moet uitgestelde belastingbates en -laste as nie-lopende bates en laste geklassifiseer word (RE 102.74) (bylae 1: § 1.3).

Uitgestelde belastingbates, wat die gevolg is van aftrekbare tydelike verskille wat deur beleggings in filiale, takke, geassosieerde entiteite en belange in gesamentlike ondernemings ontstaan, moet slegs erken word in die mate waartoe tydelike verskille in die afsienbare toekoms omgedraai sal word of waar belasbare winste beskikbaar sal wees waarteen die tydelike verskille benut kan word (RE 102.48) (bylae 1: § 1.4).

'n Uitgestelde belastingbate moet slegs vir oordraagbare ongebruikte belastingverliese en -krediete erken word in die mate waartoe dit seker is dat toekomstige belasbare winste beskikbaar sal wees waarteen die ongebruikte belastingverliese of -krediete benut kan word (RE 102.38) (bylae 1: §1.4).

\subsection{Belastinginligting in die inkomstestaat}

Indien geen voorsiening vir belasting gemaak word nie, moet hierdie feit en die redes daarvoor openbaar word (bylae 4.45) (bylae 1: $\S 2.1$ ). Verder moet die belastinguitgawe of -inkomste wat met die wins of verlies uit gewone bedrywighede verband hou afsonderlik, op die gesig van die inkomstestaat, openbaar word (bylae 4.43(d)) (bylae 1: § 2.2). Die oorsprong en klasse van belasting moet afsonderlik vir die huidige finansiële jaar gespesifiseer word (RE 102.81) (bylae 1: $\S 2.3$ ). Belasting wat vir ander finansiële jare voorsien of betaal is, moet ook afsonderlik openbaar word (RE 102.84(d)) (bylae 1: § 2.4).

Bedrae wat vir huidige en uitgestelde belasting voorsien is, aansienlike regstellings aan die voorsienings in vorige jare en regstellings aan uitgestelde belasting wat uit ' $n$ verandering in die standaard belastingkoers ontstaan het, 
moet ook afsonderlik openbaar word (RE 101.84(a), bylae 4.42(e))(bylae 1: $\S 2.5)$.

Ingevolge RE 102.62 en RE 102.65 moet huidige en uitgestelde belasting as 'n inkomste of uitgawe erken word. Dit moet ingesluit word in die netto wins of verlies vir die periode, behalwe ten opsigte van belasting wat ontstaan uit:

- 'n Transaksie of gebeurtenis wat in die ekwiteit van die maatskappy in dieselfde of vorige periodes direk erken word; of

- 'n besigheidskombinasie wat 'n verkryging is.

\subsection{Belastinginligting in die kontantvloeistaat}

Kontantvloei wat uit belastings op inkomste ontstaan, moet afsonderlik openbaar word en moet geklassifiseer word as kontantvloei uit bedryfsaktiwiteite, behalwe as dit spesifiek aan finansierings- of beleggingsaktiwiteite verwant is (bylae 1: § 3.1). Wanneer kontantvloei uit belasting oor meer as een groep aktiwiteite versprei word, moet die totale bedrag van die betaalde belasting openbaar word (bylae 1: $\S 3.2$ ). Die belastingkoste in die inkomstestaat moet gerekonsilieer word met die syfer wat as betaalde belasting in die kontantvloeistaat openbaar word (bylae 1: § 3.3). Omdat uitgestelde belasting nie kontantvloei in die huidige periode tot gevolg het nie, moet dit in die bogenoemde rekonsiliasie in aanmerking geneem word (RE 118.40, bylae 4.50(d)) (bylae 1: § 3.3).

\subsection{Belastinginligting in die aantekeninge tot die finansiële verslae}

Ingevolge RE 102 en bylae 4 van die Maatskappywet moet addisionele inligting in die aantekeninge tot die finansiële verslae openbaar word. Die totale bedrag van uitgestelde belasting en lopende belasting wat direk na ekwiteit geneem is, moet afsonderlik openbaar word (RE 102.85(a)) (bylae 1: § 4.1).

Die bedrag, asook die moontlike vervaldatum, van aftrekbare tydelike verskille, ongebruikte belastingverliese en ongebruikte belastingkrediete, waarvoor 'n uitgestelde belastingbate nie geskep is nie, behoort openbaar te word (RE 102.85(e)) (bylae 1: § 4.2).

Die totale bedrag van die tydelike verskille wat geassosieer word met beleggings in filiale, takke, geassosieerdes en belange in gesamentlike ondernemings, waarvoor geen uitgestelde belastinglas geskep is nie, moet openbaar word (RE102.85 (f)).

Ingevolge RE 102.85(g) (bylae 1: § 4.3) moet die bedrag van uitgestelde belastingbates en -laste wat in die balansstaat erken is, vir elke periode wat aangebied word, openbaar word ten opsigte van elk van die volgende:

- Tydelike verskille

- Ongebruikte belastingverliese

Meditari Accountancy Research Vol. $102002: 187-208$ 
- Ongebruikte belastingkrediete.

'n Rekonsiliasie van die openings- en sluitingsbalanse van die uitgestelde belastingbates en uitgestelde belastinglaste moet ook verskaf word (RE 102.85(i) (bylae 1: § 4.4).

Die bedrag en bewys ter ondersteuning van die erkenning van 'n belastingbate, asook die aard van die bewys ter ondersteuning van die erkenning van die bate, behoort in die volgende gevalle openbaar te word (RE 102.86):

- Wanneer die realisering van die bate daarvan afhanklik is dat toekomstige belastingwinste groter sal wees as die winste wat ontstaan het as gevolg van terugskrywings van huidige tydelike verskille; en

- Die onderneming 'n verlies gemaak het in die huidige of voorafgaande periode.

Die geskatte belastingeffek van belastingverliese of -krediete wat vir aanwending teen toekomstige belasbare inkomste beskikbaar is, moet openbaar word. Die effek voor sowel as na die aanwending om uitgestelde belasting te verminder, moet openbaar word (Bylae 4.48(a) (bylae 1: $§ 4.5$ ).

Die totale bedrag van onvoorsiene netto tydelike verskille moet openbaar word. Hierdie gedeelte van onvoorsiene verskille wat in die huidige jaar ontstaan het, moet afsonderlik openbaar word (bylae 4.48(b) (bylae 1: § 4.6).

Verder behoort die volgende hoofkomponente van die belastinguitgawe afsonderlik in die inkomstestaat openbaar te word:

- Die huidige belastinguitgawe (bylae 4.42(d), RE 102.84(a)) (bylae 1: § 4.7.1).

- Enige regstelling van belastinguitgawe, of -inkomste, wat in die huidige periode erken is en wat op vorige periodes betrekking het (bylae 4.42(e), RE 102.84(b)) (bylae 1: § 4.7.2).

- Die bedrag van uitgestelde belastinguitgawes (-inkomste) wat met die oorsprong en terugskrwying van tydelike verskille verband hou (RE 102.84 (c)) (bylae 1: $§ 4.7 .3$ ).

- Die bedrag van die uitgestelde belastinguitgawe (-inkomste) wat met 'n belastingkoersverandering of die implementering van nuwe belastings verband hou (bylae 4.42(e), RE 102.84(d)) (bylae 1: § 4.7.4).

- Die bedrag van die voordele wat ontstaan het as gevolg van 'n voorheen onerkende belastingverlies, belastingkrediet of die tydelike verskil van 'n vorige periode wat gebruik word om huidige belastinguitgawes te verminder (RE 102.84(e) (bylae 1: § 4.7.5).

- Die bedrag van die voordele wat ontstaan het as gevolg van 'n voorheen onerkende belastingverlies, belastingkrediet of tydelike verskil van 'n vorige periode wat gebruik word om uitgestelde belastinguitgawes te verminder (RE 102.84(f) (bylae 1: $§ 4.7 .6)$. 
- Uitgestelde belastinguitgawes wat ontstaan as gevolg van die afskrywing, of terugskrywing van 'n vorige afskrywing van 'n uitgestelde belastingbate, as gevolg van 'n hersiening van die drawaarde op die balansstaatdatum (RE 102.84(g) (bylae 1: § 4.7.7).

- Die bedrag betaal aan SBM (RE 303.08) (bylae 1: $\S$ 4.7.8), die bedrag voorsien vir SBM (RE 303.08) (bylae 1: § 4.7.8) asook die bedrag van onbenutte SBM-krediete (RE 303.08) (bylae 1 : $\S$ 4.7.8) wanneer dividendinkomste die verklaarde dividend oorskry. Dit is belangrik om daarop te let dat hierdie vereiste uit 'n Rekeningkundige Opinie-reeks kom (300-reeks) en gevolglik sal die nie-nakoming van hierdie vereiste nie die nie-nakoming van algemeen aanvaarde rekeningkundige praktyk beteken nie.

Ingevolge RE 102.85(c) moet die belastinguitgawe (-inkomste) wat verband hou met buitengewone items wat gedurende die periode erken is, afsonderlik openbaar word (bylae 1: $\S 4.8$ ).

RE 102.85(c) (bylae 1: § 4.9), bepaal dat 'n verduideliking verskaf moet word van die verhouding tussen die belastinguitgawe (-inkomste) en die rekeningkundige wins in een of beide van die volgende vorme:

- 'n Numeriese rekonsiliasie van die belastinguitgawe of -inkomste en die produk van die rekeningkundige wins vermenigvuldig met die toepaslike belastingkoers.

- 'n Numeriese rekonsiliasie van die gemiddelde effektiewe belastingkoers en die toepaslike belastingkoers.

Indien 'n verandering in die toepaslike belastingkoers in vergelyking met vorige jare plaasvind, moet 'n verduideliking daarvan ook verskaf word (RE 102.85(d)) (bylae 1: $§ 4.9)$.

Bylae 4.48(a) en bylae 4.48(b) bepaal dat die verwagte belastingverliese wat vir toekomstige aanwending teen belastinginkomste beskikbaar is, sowel as die totale onvoorsiene tydelike verskille, openbaar moet word voordat sowel as nadat dit gebruik is om die uitgestelde belasting te verminder Die bedrae wat met die huidige periode verband hou, moet afsonderlike openbaar word (bylae 1: $\S 4.5)$.

\subsection{Opsomming}

Uit die bostaande analise van bylae 4 van die Maatskappywet asook RE 102 en RE 303 is dit duidelik dat die vereistes vir die openbaarmaking van belastinginligting baie wydlopend is en dat die gebruikers van finansiële verslae baie omvattende inligting oor belasting uit hierdie verslae kan verkry. Dit is verder duidelik dat maatskappye deeglik van al vereistes bewus moet wees om te verseker dat hulle wel daaraan voldoen.

Vervolgens word verslag gedoen oor 'n ondersoek na die mate waartoe top maatskappye in Suid-Afrika voldoen aan die vereistes vir openbaarmaking van

Meditari Accountancy Research Vol. $102002: 187-208$ 
belastinginligting in finansiële verslae wat hierbo uiteengesit word. Dit word gedoen aan die hand van ' $n$ ontleding van die jongste gepubliseerde finansiële verslae van top genoteerde maatskappye in Suid-Afrika.

\section{Empiriese ondersoek na die nakoming van die openbaarmakingsvereistes}

\subsection{Metode van seleksie van die maatskappye}

Die maatskappye wat in die ondersoek ingesluit is, is deur middel van ewekansige steekproefneming geselekteer. Die metode van steekproefneming word soos volg deur Steyn, Smit en Du Toit (1989:18) beskryf:

"n Eenvoudige ewekansige steekproef word verkry indien elke element van die populasie wat nog nie in die steekproef opgeneem is nie, 'n gelyke kans het om gekies te word in die eersvolgende trekking."

Die trekking is gedoen met behulp van die kanssyfers wat in die statistiese tabelle in Steyn et al (1989:548) verskyn. 'n Steekproefgroote van 10 is gebruik. Maatskappye is derhalwe uit die lys van die top 200 maatskappye gekies in terme van hul markkapitalisasie wat in Finansies en Tegniek van Maart 2002 gepubliseer is (Hasenfus 2002:20-23).

Die maatskappye wat in die ondersoek ingesluit is, is soos volg geselekteer:

- Syfers is gekies uit die kanssyfertabel wat in tabel B1 in Steyn et al (1989: 548) verskyn.

- Ry 5 in kolom 8 is willekeurig as beginpunt gekies en getalle is gekies deur van links na regs vanaf die beginpunt te lees.

- Die volgende getalle is gekies en in groepe van drie geplaas om te verseker dat al 200 maatskappye in die lys wel 'n kans staan om gekies te word:

$585 ; 311 ; 810 ; 094 ; 862 ; 826 ; 238 ; 768 ; 117 ; 665 ; 806 ; 419 ; 478$; $339 ; 907 ; 351 ; 072 ; 730 ; 682 ; 675 ; 423 ; 335 ; 118 ; 803 ; 831 ; 700$; $298 ; 294 ; 504 ; 239 ; 416 ; 737 ; 669 ; 775 ; 985 ; 402 ; 236 ; 081 ; 961$; $308 ; 792 ; 848 ; 017 ; 228 ; 260 ; 795 ; 838 ; 976 ; 193 ; 546 ; 624 ; 664$; $305 ; 835 ; 627 ; 525 ; 685 ; 253 ; 642 ; 849 ; 576 ; 652 ; 705 ; 474 ; 977$; $637,480,283 ; 036 ; 359 ; 785 ; 525 ; 542 ; 299 ; 443 ; 935 ; 845 ; 073$; $516 ; 877 ; 815 ; 877 ; 815 ; 524 ; 373 ; 772 ; 359 ; 654 ; 054$

$\mathrm{Al}$ die groepe getalle wat kleiner of gelyk aan 200 (die populasiegrootte) is, is in die steekproef ingesluit.

\subsection{Metode van evaluering}

Die jongste gepubliseerde finansiële verslae van die geselekteerde maatskappye is verkry en die inligting wat in hierdie finansiële verslae verskyn, is vir die beoordeling gebruik. Die vereistes vir die openbaarmaking van 
belastinginligting, wat in paragraaf 2 hierbo ontleed word, is opgesom en in bylae 1 gelys.

Die effektiewe datum van RE 102 (gewysig) is 1 Julie 1999 (RE 102.93). Dit beteken dat die standpunt van toepassing is op alle finansiële state wat voorberei word vir periodes wat op of na 1 Julie 1999 begin. Gevolglik is die standpunt van toepassing op al die geselekteerde finansiële state wat in die ondersoek betrek is. Die openbaarmaking in die finansiële verslae is vervolgens gemeet aan die vereistes wat in bylae 1 uiteengesit word. Waar onvoldoende inligting in die finansiële state beskikbaar was, en die moontlikheid bestaan het dat die vereiste nie op die betrokke maatskappye van toepassing mag wees nie, is die vereiste as "nie van toepassing nie" aangedui. In die verduidelikende aantekening in die ontleding is 'n verwysing verskaf na waar die inligting in die finansiële verslae openbaar is.

Die ontleding van die finansiële state van die geselekteerde entiteite maak dit moontlik om die persentasie van nakoming van die vereistes vir openbaarmaking van belastinginligting te bepaal. Dit is gedoen deur die aantal voorvalle van voldoening aan die vereistes uit te druk as 'n persentasie van die totale aantal geleenthede waarin dit moontlik was om aan die vereistes te voldoen. Indien bepaalde vereistes nie op die betrokke entiteit van toepassing was nie, is daardie vereistes nie in die berekening van die persentasie in ag geneem nie.

\subsection{Resultate van die ondersoek}

\subsubsection{Ontleding van die resultate - vereistes ten opsigte van die} balansstaat

\begin{tabular}{|c|c|c|c|c|}
\hline 1. Balansstaat & Nagekom & $\begin{array}{c}\text { Nie nagekom } \\
\text { nie }\end{array}$ & $\begin{array}{c}\text { Nie van } \\
\text { toepassing }\end{array}$ & $\begin{array}{c}\text { Persentasie } \\
\text { nakoming }\end{array}$ \\
\hline $\begin{array}{l}\text { Belastingbates en -laste moet afsonderlik van } \\
\text { ander bates en laste van die maatskappy } \\
\text { vertoon word }\end{array}$ & 9 & 0 & 1 & $100 \%$ \\
\hline $\begin{array}{l}\text { Uitgestelde belastingbates en -laste moet van } \\
\text { lopende belastingbates en -laste onderskei word }\end{array}$ & 10 & 0 & 0 & $100 \%$ \\
\hline $\begin{array}{l}\text { Uitgestelde belastingbates en -laste moet as } \\
\text { nie-lopende bates en laste geklassifiseer word. }\end{array}$ & 10 & 0 & 0 & $100 \%$ \\
\hline \begin{tabular}{|l} 
Uitgestelde belastingbates moet slegs erken \\
word vir oordraagbare ongebruikte \\
belastingverliese en -krediete in die mate \\
waartoe dit seker is dat daar toekomstige \\
belasbare winste beskikbaar sal wees waarteen \\
die ongebruikte belastingverliese of -krediete \\
benut kan word.
\end{tabular} & 9 & 0 & 1 & $100 \%$ \\
\hline
\end{tabular}

Meditari Accountancy Research Vol. 102002 : 187-208 


\begin{tabular}{||l|c|c|c|c|}
\hline Totaal & 38 & 0 & 2 & $100 \%$ \\
\hline
\end{tabular}


Die bostaande inligting dui aan dat daar wel deeglik aandag aan die vereistes vir openbaarmaking van belastinginligting in die balansstaat geskenk word. Die feit dat al die geselekteerde maatskappye ten volle aan die vereistes vir die openbaarmaking van die belastinginligting op die balansstaat voldoen, dui daarop dat entiteite bewus is van die vereistes ten opsigte van openbaarmaking en dat daar gepoog word om volledige inligting aan gebruikers van die finansiële verslae beskikbaar te stel.

\subsubsection{Ontleding van die resultate - vereistes ten opsigte van die} inkomstestaat

\begin{tabular}{|c|c|c|c|c|}
\hline 2. Inkomstestaat & Nagekom & $\begin{array}{c}\text { Nie } \\
\text { nagekom nie }\end{array}$ & $\begin{array}{c}\text { Nie van } \\
\text { toepassing nie }\end{array}$ & $\begin{array}{r}\text { Persentasie } \\
\text { nakoming }\end{array}$ \\
\hline $\begin{array}{l}\text { 2.1 Indien geen voorsiening vir } \\
\text { belasting gemaak word nie, } \\
\text { moet hierdie feit en die redes } \\
\text { daarvoor openbaar word }\end{array}$ & 0 & 0 & 10 & N.v.t. \\
\hline $\begin{array}{l}\text { 2.2 Die belastinguitgawe of } \\
\text {-inkomste wat met gewone } \\
\text { bedrywighede verband hou, } \\
\text { moet afsonderlik op die gesig } \\
\text { van die inkomstestaat openbaar } \\
\text { word }\end{array}$ & 10 & 0 & 0 & $100 \%$ \\
\hline $\begin{array}{l}2.3 \text { Die oorsprong en klasse van } \\
\text { belasting moet afsonderlik vir } \\
\text { die huidige finansiële jaar } \\
\text { gespesifiseer word }\end{array}$ & 10 & 0 & 0 & $100 \%$ \\
\hline $\begin{array}{l}\text { 2.4 Belasting voorsien of betaal vir } \\
\text { ander finansiële jare moet } \\
\text { afsonderlik openbaar word }\end{array}$ & 10 & 0 & 0 & $100 \%$ \\
\hline $\begin{array}{l}\text { 2.5 Bedrae wat vir huidige en } \\
\text { uitgestelde belasting voorsien is, } \\
\text { aansienlike regstellings aan } \\
\text { vorige jare se voorsienings en } \\
\text { regstellings aan uitgestelde } \\
\text { belasting wat as gevolg van } \\
\text { verandering in die standaard } \\
\text { belastingkoers ontstaan het, } \\
\text { behoort afsonderlik openbaar te } \\
\text { word. }\end{array}$ & 10 & 0 & 0 & $100 \%$ \\
\hline Totaal & 40 & 0 & 10 & $100 \%$ \\
\hline
\end{tabular}


Uit die bostaande ontleding blyk dit dat, vir die doeleindes van hierdie ondersoek, daar ten volle aan die vereistes vir openbaarmaking van belastinginligting in die inkomstestaat voldoen word. Sommige vereistes is nie op al die entiteite van toepassing nie, maar vir sover die vereistes wel van toepassing is, word daaraan voldoen.

\subsubsection{Ontleding van die resultate - vereistes ten opsigte van die} kontantvloeistaat

\begin{tabular}{|c|c|c|c|c|}
\hline 3. Kontantvloeistaat & Nagekom & $\begin{array}{c}\text { Nie } \\
\text { nagekom } \\
\text { nie }\end{array}$ & $\begin{array}{c}\text { Nie van } \\
\text { toepassing nie }\end{array}$ & $\begin{array}{c}\text { Persentasie } \\
\text { nakoming }\end{array}$ \\
\hline $\begin{array}{l}\text { 3.1 Kontantvloei wat uit } \\
\text { belastings op inkomste } \\
\text { ontstaan, moet afsonderlik } \\
\text { van kontantvloei uit } \\
\text { bedryfsaktiwiteite openbaar } \\
\text { en geklassifiseer word, } \\
\text { behalwe as dit spesifiek aan } \\
\text { finansierings- of } \\
\text { beleggingsaktiwiteite } \\
\text { verwant is }\end{array}$ & 9 & 1 & 0 & $90 \%$ \\
\hline $\begin{array}{l}\text { 3.2 As kontantvloei uit belasting } \\
\text { oor meer as een aktiwiteit } \\
\text { versprei word, moet die totale } \\
\text { bedrag van betaalde belasting } \\
\text { openbaar word }\end{array}$ & 9 & 1 & 0 & $90 \%$ \\
\hline $\begin{array}{l}\text { 3.3 Die belastingkoste in die } \\
\text { inkomstestaat moet } \\
\text { gerekonsilieer word met die } \\
\text { syfer wat as betaalde } \\
\text { belasting in die } \\
\text { kontantvloeistaat openbaar } \\
\text { word }\end{array}$ & 6 & 4 & 0 & $60 \%$ \\
\hline Totaal & 24 & 6 & 0 & $80 \%$ \\
\hline
\end{tabular}

Die nakoming van die vereistes ten opsigte van openbaarmaking van belastinginligting in die kontantvloeistaat is die area van die finansiële verslae waarin die geselekteerde maatskappye die swakste presteer. Die swakste voldoening is ten opsigte van die vereiste dat daar 'n rekonsiliasie tussen die belastingkoste soos per inkomstestaat en die kontantvloei as gevolg van belasting moet wees. Daar word egter nie ten volle aan enigeen van die vereistes voldoen nie. Dit blyk dat hierdie area van openbaarmaking die meeste aandag sal moet geniet ten einde te verseker dat die gebruikers toegang tot al die vereiste inligting sal kan verkry.

Een van die geselekteerde maatskappye voldoen nie aan enigeen van die vereistes nie, terwyl drie maatskappye nie aan al die vereistes voldoen nie. Derhalwe blyk daar ruimte vir verbetering te wees wat betref die 
openbaarmaking van belastinginligting in die kontanvloeistaat van die finansiële verslae.

\subsubsection{Ontleding van die resultate - vereistes ten opsigte van} aantekeninge tot die finansiële verslae

\begin{tabular}{|c|c|c|c|c|c|}
\hline 4. & $\begin{array}{l}\text { Aantekeninge tot die finansiële } \\
\text { verslae }\end{array}$ & Nagekom & $\begin{array}{c}\text { Nie } \\
\text { nagekom nie }\end{array}$ & $\begin{array}{c}\text { Nie van } \\
\text { toepassing nie }\end{array}$ & $\begin{array}{c}\text { Persentasie } \\
\text { nakoming }\end{array}$ \\
\hline 4.1 & $\begin{array}{l}\text { Die totale bedrag van uitgestelde } \\
\text { belasting asook lopende belasting } \\
\text { wat direk na ekwiteit geneem is, } \\
\text { moet afsonderlik openbaar word }\end{array}$ & 2 & 0 & 8 & $100 \%$ \\
\hline 4.2 & $\begin{array}{l}\text { Die bedrag, asook die moontlike } \\
\text { vervaldatum van aftrekbare } \\
\text { tydelike verskille, ongebruikte } \\
\text { belastingverliese en ongebruikte } \\
\text { belastingkrediete waarvoor daar nie } \\
\text { 'n uitgestelde belastingbate geskep } \\
\text { is nie, behoort openbaar te word. }\end{array}$ & 8 & 2 & 0 & $80 \%$ \\
\hline 4.3 & $\begin{array}{l}\text { Die bedrag van uitgestelde } \\
\text { belastingbates en -laste wat in die } \\
\text { balansstaat erken is vir elke periode } \\
\text { wat aangebied word, moet } \\
\text { openbaar word t.o.v. elkeen van die } \\
\text { volgende: } \\
\text { - Tydelike verskille } \\
\text { - Ongebruikte belastingverliese } \\
\text { - Ongebruikte belastingkrediete }\end{array}$ & 9 & 0 & 1 & $100 \%$ \\
\hline 4.4 & $\begin{array}{l}\text { 'n Rekonsiliasie moet van die } \\
\text { openings- en sluitingsbalanse van } \\
\text { die uitgestelde belastingbates en - } \\
\text { laste verskaf word }\end{array}$ & 9 & 0 & 1 & $100 \%$ \\
\hline 4.5 & $\begin{array}{l}\text { Die geskatte belastingeffek van } \\
\text { belastingverliese of -krediete wat } \\
\text { beskikbaar is vir aanwending teen } \\
\text { toekomstige belasbare inkomste } \\
\text { moet openbaar word. Die effek } \\
\text { voor die aanwending, asook na die } \\
\text { aanwending daarvan om uitgestelde } \\
\text { belasting te verminder, moet } \\
\text { openbaar word }\end{array}$ & 9 & 0 & 1 & $100 \%$ \\
\hline 4.6 & $\begin{array}{l}\text { Die totale bedrag van onvoorsiene } \\
\text { netto tydelike verskille moet } \\
\text { openbaar word, met afsonderlike } \\
\text { aanduiding van die gedeelte wat op } \\
\text { die huidige jaar van toepassing is }\end{array}$ & 7 & 0 & 3 & $100 \%$ \\
\hline
\end{tabular}

Meditari Accountancy Research Vol. 102002 : 187-208 
Tabel 3.3.4 (vervolg)

\begin{tabular}{|c|c|c|c|c|c|}
\hline \multicolumn{6}{|c|}{$\begin{array}{l}\text { 4.7 Die volgende hoofkomponente van } \\
\text { die belastinguitgawe in die } \\
\text { inkomstestaat behoort afsonderlik } \\
\text { openbaar te word: }\end{array}$} \\
\hline 4.7 .1 & Die huidige belastinguitgawe & 10 & 0 & 0 & $100 \%$ \\
\hline 4.7 .2 & $\begin{array}{l}\text { Regstelling van vorige jare se } \\
\text { belastinguitgawe in die huidige } \\
\text { jaar }\end{array}$ & 10 & 0 & 0 & $100 \%$ \\
\hline 4.7 .3 & $\begin{array}{l}\text { Die bedrag van uitgestelde } \\
\text { belastinguitgawe/-inkomste wat } \\
\text { met die oorsprong en } \\
\text { terugskrywing van tydelike } \\
\text { verskille verband hou }\end{array}$ & 8 & 2 & 0 & $80 \%$ \\
\hline 4.7 .4 & $\begin{array}{l}\text { Die bedrag van uitgestelde } \\
\text { belasting wat met 'n } \\
\text { koersverandering verband hou }\end{array}$ & 3 & 0 & 7 & $100 \%$ \\
\hline 4.7 .5 & $\begin{array}{l}\text { Die bedrag van voordele wat } \\
\text { ontstaan a.g.v. 'n voorheen } \\
\text { onerkende belastingverlies, } \\
\text { belastingkrediet of tydelike } \\
\text { verskil van 'n vorige periode wat } \\
\text { gebruik word om huidige } \\
\text { belastinguitgawes te verminder. }\end{array}$ & 6 & 1 & 3 & $86 \%$ \\
\hline 4.7 .6 & $\begin{array}{l}\text { Die bedrag van voordele wat } \\
\text { ontstaan a.g.v. 'n voorheen } \\
\text { onerkende belastingverlies, } \\
\text { belastingkrediet of tydelike } \\
\text { verskil van 'n vorige periode wat } \\
\text { gebruik word om uitgestelde } \\
\text { belasting te verminder }\end{array}$ & 8 & 1 & 1 & $89 \%$ \\
\hline 4.7 .7 & $\begin{array}{l}\text { Uitgestelde belastinguitgawes } \\
\text { wat ontstaan a.g.v. die } \\
\text { afskrywing van 'n uitgestelde } \\
\text { belastingbate of a.g.v. 'n } \\
\text { hersiening in die drawaarde op } \\
\text { die balansstaatdatum }\end{array}$ & 2 & 0 & 8 & $100 \%$ \\
\hline 4.7 .8 & $\begin{array}{l}\text { Die bedrag betaal aan SBM. Die } \\
\text { bedrag voorsien vir SBM asook } \\
\text { 'n aanduiding van onbenutte } \\
\text { SBM-krediete* }\end{array}$ & 7 & 1 & 2 & $88 \%$ \\
\hline
\end{tabular}


Tabel 3.3.4 (vervolg)

\begin{tabular}{|c|c|c|c|c|}
\hline $\begin{array}{l}\text { 4.8 Die belastinguitgawe of -inkomste } \\
\text { wat verband hou met buitengewone } \\
\text { items deur die jaar erken, moet } \\
\text { afsonderlik openbaar word }\end{array}$ & 2 & 5 & 3 & $29 \%$ \\
\hline $\begin{array}{l}4.9 \text { 'n Verduideliking van die } \\
\text { verhouding tussen die } \\
\text { belastinguitgawe of -inkomste en } \\
\text { die rekeningkundige wins moet } \\
\text { verskaf word }\end{array}$ & 10 & 0 & 0 & $100 \%$ \\
\hline $\begin{array}{l}4.10 \text { 'n Verduideliking van 'n } \\
\text { verandering in die toepaslike } \\
\text { belastingkoers in vergelyking met } \\
\text { vorige jare, indien van toepassing, } \\
\text { moet verskaf word }\end{array}$ & 3 & 0 & 7 & $100 \%$ \\
\hline Totaal & 113 & 12 & 45 & $90 \%$ \\
\hline
\end{tabular}

* Hierdie vereiste is in terme van RE 303 en is derhalwe nie 'n vereiste vir die nakoming van algemeen aanvaarde rekeningkundige praktyk nie.

Alhoewel twee maatskappye nie aan vereiste 4.2 voldoen nie, is dit moontlik dat daar geen inligting is wat geopenbaar behoort te word nie. Hierdie feit kan egter nie uit die state self afgelei word nie. Die ander vereistes ten opsigte van uitgestelde belasting wat nie nagekom is nie is beslis op die onderskeie entiteite van toepassing. Een groot genoteerde maatskappy het wel dividende verklaar, maar nie die SBM-verpligting afsonderlik aangetoon nie. Dit mag wees dat die netto bedrag van dividende ontvang, die bedrag van betaalde dividende oorskry, maar daar is geen inligting in die state om dit te kan vasstel nie. Verder het vyf maatskappye wel buitengewone items in hulle inkomstestate ingesluit, maar die belastingeffek is nie afsonderlike openbaar nie. Dit mag wees dat daar in sommige gevalle geen belastingeffek is nie, maar hierdie inligting word nie aan die gebruikers van die verslae deurgegee nie.

Alhoewel ruimte vir verbetering bestaan, blyk dit dat die inligting wat die gebruikers in die aantekeninge ontvang tot 'n baie groot mate wél in hulle behoeftes sal kan voorsien.

\section{Samevatting}

Uit die ontleding van die finansiële verslae van die geselekteerde top maatskappye is dit duidelik dat top maatskappye in Suid-Afrika wél in 'n groot mate voldoen aan die openbaarmakingsvereistes wat deur die onderskeie owerhede daargestel is om die gebruikers van die finansiële verslae te beskerm. Die geselekteerde maatskappye voldoen in geheel (100\%) aan die vereistes wat vir die openbaarmaking in die balansstaat en inkomstestaat gestel word. Die area waarin die swakste prestasie gelewer word, is die nakoming van die vereistes vir openbaarmaking in die kontantvloeistaat. In vergelyking met die 
ander drie areas, het die geselekteerde entiteite op hierdie gebied swakker gevaar. Dit was veral die gebrek aan openbaarmaking van inligting wat die verskil tussen belasting in die inkomstestaat en kontantvloei as gevolg van belasting verduidelik, wat tot die swakker prestasie op hierdie gebied aanleiding gegee het. Alhoewel die maatskappye 'n 90\% voldoeningsvlak behaal ten opsigte van die openbaarmaking van inligting in die aantekeninge, is die vereiste met betrekking tot die openbaarmaking van die belastingeffek op buitengewone items slegs op die vlak van $29 \%$ nagekom. Hierdie vereiste is derhalwe die een wat die swakste nagekom word.

Indien aanvaar word dat die onderskeie owerhede daarna streef om optimum openbaarmakingsvereistes daar te stel, en dit blyk uit hierdie ondersoek dat die verskaffers van die finansiële verslae daarna streef om aan hierdie vereistes te voldoen, behoort die gebruikers van finansiële verslae voldoende inligting tot hulle beskikking te hê om finansiële verslae as 'n nuttige bron van inligting vir besluitneming te kan gebruik.

Ten einde te verseker dat daar altyd aan die behoeftes van die gebruikers van finansiële verslae voldoen word, behoort die owerhede deurlopend ondersoek na die relevansie van die vereistes vir openbaarmaking in te stel. Terselfdertyd behoort die verskaffers van finansiële verslae deurlopend hulself aan hierdie vereistes te meet om sodoende volkome nakoming te verseker. Dit blyk uit die ondersoek dat die verskaffers van die verslae poog om hul deel van die ooreenkoms na te kom. Aangesien die vereistes statutêr gereguleer word, is daar eintlik geen rede waarom enige maatskappy van enigeen van die vereistes vrygestel hoef te word nie en daar moet beslis steeds gepoog word om 'n openbaarmakingsvlak van $100 \%$ vir alle entiteite te bewerkstellig.

Die owerhede verseker dat die vereistes relevant bly deur die vereistes aan te pas indien dit nodig blyk te wees. Alhoewel hierdie studie uitgevoer is met verwysing na RE 102 (gewysig in Maart 1999), omdat hierdie standpunt van toepassing is op die jaareindes van die maatskappye wat in die studie ingesluit is, is daar reeds 'n gewysigde RE 102 waaraan voldoen moet word. Hierdie gewysigde RE 102 is in April 2001 uitgebring en is van toepassing op jaareindes wat op of na 1 Januarie 2001 begin. Verder is besprekingsdokument GK 153 gepubliseer wat oor die hantering van sekondêre belasting in maatskappye handel. Indien hierdie konsep aanvaar word, sal die huidige RE 303 geskrap word en 'n nuwe standpunt tot die 500-reeks bygevoeg word, naamlik RE 501.

Dit is onrusbarend dat al die gekose maatskappye oor ongekwalifiseerde ouditverslae ten opsigte van hulle finansiële verslae beskik. 'n Ouditeur verklaar in sy verslag dat die state aan Algemene Aanvaarde Rekeningkundige Praktyk voldoen soos deur die Maatskappywet vereis. Die gebruiker behoort derhalwe te kan vertrou dat die nakoming volkome is. Hoe moet gebruikers weet in watter mate op die state vertrou kan word indien hulle nie weet watter openbaarmakingsvereistes nie nagekom is nie? Alhoewel die state die verantwoordelikheid van die direkteure is, het die ouditeur 
'n verantwoordelikheid teenoor die gebruiker om oor die nakoming van hierdie verantwoordelikheid verslag te doen.

Dit is moontlik dat die vlak van nakoming van openbaarmakingsvereistes hoër is vir die top maatskappye as vir die ander maatskappye in die land. Die direkteure en ouditeure doen gewoonlik meer moeite met hierdie state, omdat die state wyer versprei word en gewoonlik indringend onder die soeklig kom.

\section{Bylaag 1}

\section{Kontrolelys vir evaluering van die nakoming van vereistes vir openbaarmaking van belastinginligting in finansiële verslae}

Vervolgens sal daar 'n kontrolelys saamgestel word wat gebruik gaan word in die evaluering van die nakoming van die vereistes vir openbaarmaking van belastinginligting in die finansiële verslae. Hierdie kontrolelys sal gebruik word vir beoordeling van die nakoming van die vereistes vir elke geselekteerde maatskappy.

\begin{tabular}{|c|c|}
\hline Openbaarmakingsvereiste & $\begin{array}{l}\text { Verwysing soos gebruik in } \\
\text { Hoofstuk } 3\end{array}$ \\
\hline \multicolumn{2}{|l|}{ 1. Balansstaat } \\
\hline $\begin{array}{l}\text { 1.1 Belastingbates en -laste moet afsonderlik van ander bates en } \\
\text { laste van die maatskappy vertoon word. }\end{array}$ & $\begin{array}{l}\text { RE } 102.73 \\
\text { Bylae } 4.16(\mathrm{c})\end{array}$ \\
\hline $\begin{array}{l}\text { 1.2 Uitgestelde belastingbates en -laste moet onderskei word van } \\
\text { lopende belastingbates en -laste. }\end{array}$ & RE 102.73 \\
\hline $\begin{array}{l}\text { 1.3 Uitgestelde belastingbates en -laste moet geklassifiseer word as } \\
\text { nie-lopende bates en laste. }\end{array}$ & RE 102.74 \\
\hline $\begin{array}{l}\text { 1.4 Uitgestelde belastingbates moet slegs erken word vir } \\
\text { oordraagbare ongebruikte belastingverliese en -krediete tot die } \\
\text { mate waartoe dit seker is dat daar toekomstige belasbare winste } \\
\text { beskikbaar sal wees waarteen die ongebruikte belastingverliese } \\
\text { of -krediete benut kan word. }\end{array}$ & $\begin{array}{l}\text { RE } 102.48 \\
\text { RE } 102.38\end{array}$ \\
\hline \multicolumn{2}{|l|}{ 2. Inkomstestaat } \\
\hline $\begin{array}{l}\text { 2.1 As daar geen voorsiening gemaak word vir belasting nie, moet } \\
\text { hierdie feit en redes daarvoor openbaar word. }\end{array}$ & Bylae 4.45 \\
\hline $\begin{array}{l}\text { 2.2 Die belastinguitgawe of -inkomste wat verband hou met } \\
\text { gewone bedrywighede, moet afsonderlik op die gesig van die } \\
\text { inkomstestaat openbaar word. }\end{array}$ & Bylae 4.42 (d) \\
\hline $\begin{array}{l}\text { 2.3 Die oorsprong en klasse van belasting moet afsonderlik vir die } \\
\text { huidige finansiële jaar gespesifiseer word. }\end{array}$ & RE 102.81 \\
\hline
\end{tabular}

Meditari Accountancy Research Vol. $102002: 187-208$ 
Inkomstestaat (vervolg)

\begin{tabular}{|c|c|}
\hline $\begin{array}{l}\text { 2.4 Belasting voorsien of betaal vir ander finansiële jare moet } \\
\text { afsonderlik openbaar gemaak word. }\end{array}$ & RE 102.84 (d) \\
\hline \begin{tabular}{|l} 
2.5 Bedrae wat voorsien is vir huidige en uitgestelde belasting, \\
aansienlike regstellings aan vorige jare se voorsienings en \\
regstellings aan uitgestelde belasting wat ontstaan het as gevolg \\
van verandering in die standaard belastingkoers, behoort \\
afsonderlik openbaar te word.
\end{tabular} & $\begin{array}{l}\text { RE } 101.84(\mathrm{a}) \\
\text { Bylae } 4.42(\mathrm{e})\end{array}$ \\
\hline \multicolumn{2}{|l|}{ 3. Kontantvloeistaat } \\
\hline $\begin{array}{l}\text { 3.1 Kontantvloei wat ontstaan uit belastings op inkomste moet } \\
\text { afsonderlik openbaar en geklassifiseer word as kontantvloei uit } \\
\text { bedryfsaktiwiteite, behalwe as dit spesifiek verwant is aan } \\
\text { finansierings- of beleggingsaktiwiteite. }\end{array}$ & Bylae 4.50 (d) \\
\hline $\begin{array}{l}\text { 3.2 As kontantvloei uit belasting oor meer as een aktiwiteit versprei } \\
\text { word, moet die totale bedrag belasting betaal openbaar word. }\end{array}$ & Bylae $4.50(\mathrm{~d})$ \\
\hline $\begin{array}{l}\text { 3.3 Die belastingkoste in die inkomstestaat moet gerekonsilieer } \\
\text { word met die syfer wat as belasting betaal in die } \\
\text { kontantvloeistaat openbaar word. }\end{array}$ & $\begin{array}{l}\text { RE } 118.40 \\
\text { Bylae } 4.50(d)\end{array}$ \\
\hline \multicolumn{2}{|l|}{ 4. Aantekeninge tot die finansiële verslae } \\
\hline $\begin{array}{l}\text { 4.1 Die totale bedrag uitgestelde belasting asook lopende belasting } \\
\text { wat direk na ekwiteit geneem is, moet afsonderlik openbaar } \\
\text { word. }\end{array}$ & RE 102.85 (a) \\
\hline \begin{tabular}{|l} 
4.2 Die bedrag, asook die moontlike vervaldatum van aftrekbare \\
tydelike verskille, ongebruikte belastingverliese asook \\
ongebruikte belastingkrediete waarvoor daar nie 'n uitgestelde \\
belasting bate geskep is nie, behoort openbaar te word.
\end{tabular} & RE $102.85(\mathrm{e})$ \\
\hline \begin{tabular}{|l} 
4.3 Die bedrag uitgestelde belastingbates en -laste wat erken is in \\
die balansstaat vir elke periode wat aangebied word, moet \\
openbaar word t.o.v. elke tipe van die volgende: \\
4.3.1 Tydelike verskille \\
4.3.2 \\
4.3.3 \\
Ongebruikte belastingverliese, en \\
\end{tabular} & RE $102.85(\mathrm{~g})$ \\
\hline \begin{tabular}{|l}
4.4 'n Rekonsiliasie moet verskaf word tussen die openings- en \\
sluitingsbalans van die uitgestelde belastingbates en - laste.
\end{tabular} & RE 102.85 (i) \\
\hline $\begin{array}{l}\text { 4.5 Die geskatte belastingeffek van belastingverliese of -krediete } \\
\text { wat beskikbaar is vir aanwending teen toekomstige belasbare } \\
\text { inkomste, moet openbaar word. Die effek voor die aanwending, } \\
\text { asook na die aanwending daarvan om uitgestelde belasting te } \\
\text { verminder, moet openbaar word. }\end{array}$ & Bylae 4.48 (a) \\
\hline
\end{tabular}


Aantekeninge tot die finansiële verslae (vervolg)

\begin{tabular}{|c|c|}
\hline $\begin{array}{l}\text { 4.6 Die totale bedrag van onvoorsiene netto tydelike verskille moet } \\
\text { openbaar word, met die gedeelte wat van toepassing is op die } \\
\text { huidige jaar afsonderlik aangedui. }\end{array}$ & Bylae 4.48 (b) \\
\hline $\begin{array}{l}\text { 4.7 Die volgende hoofkomponente van die belastinguitgawe in die } \\
\text { inkomstestaat behoort afsonderlik openbaar te word: }\end{array}$ & \\
\hline 4.7.1 Die huidige belastinguitgawe & Bylae 4.42(d), RE 102.84 (a) \\
\hline $\begin{array}{l}\text { 4.7.2 Regstelling van vorige jare se belastinguitgawe in die } \\
\text { huidige jaar. }\end{array}$ & Bylae 4.42(e), RE 102.84 (b) \\
\hline $\begin{array}{l}\text { 4.7.3 Die bedrag vir uitgestelde belastinguitgawe/-inkomste wat } \\
\text { verband hou met die oorsprong en terugskrywing van } \\
\text { tydelike verskille. }\end{array}$ & RE $102.84(\mathrm{c})$ \\
\hline $\begin{array}{l}\text { 4.7.4 Die bedrag uitgestelde belasting wat verband hou met 'n } \\
\text { koersverandering. }\end{array}$ & $\begin{array}{l}\text { Bylae } 4.42(\mathrm{e}), \mathrm{RE} 102.84 \\
\text { (d) }\end{array}$ \\
\hline \begin{tabular}{|l} 
4.7.5 Die bedrag van voordele wat ontstaan a.g.v. 'n voorheen \\
onerkende belastingverlies, belastingkrediet, of tydelike \\
verskil van 'n vorige periode wat gebruik word om huidige \\
belastinguitgawes te verminder.
\end{tabular} & $\begin{array}{l}\text { RE } 102.84(\mathrm{e}) \text {, Bylae } 4.48 \text { (a), } \\
\text { Bylae } 4.48 \text { (b) }\end{array}$ \\
\hline $\begin{array}{l}\text { 4.7.6 Die bedrag van voordele wat ontstaan a.g.v. 'n voorheen } \\
\text { onerkende belastingverlies, belastingkrediet, of tydelike } \\
\text { verskil van 'n vorige periode wat gebruik word om } \\
\text { uitgestelde belasting te verminder. }\end{array}$ & RE 102.84 (f) \\
\hline \begin{tabular}{|ll} 
4.7.7 Uitgestelde belastinguitgawes wat ontstaan a.g.v. die \\
afskrywing van 'n uitgestelde belastingbate of a.g.v. 'n \\
hersiening in die drawaarde op balansstaatdatum.
\end{tabular} & RE $102.84(\mathrm{~g})$ \\
\hline \begin{tabular}{|l} 
4.7.8 Die bedrag betaal aan SBM. Die bedrag voorsien vir SBM, \\
asook 'n aanduiding van onbenutte SBM krediete.
\end{tabular} & RE 303.08 \\
\hline $\begin{array}{l}\text { 4.8 Die belastinguitgawe/-inkomste wat verband hou met } \\
\text { buitengewone items erken deur die jaar, moet afsonderlik } \\
\text { openbaar word. }\end{array}$ & RE 102.85 (c) \\
\hline $\begin{array}{l}4.9 \text { 'n Verduideliking moet verskaf word oor die verhouding } \\
\text { tussen die belastinguitgawe/-inkomste en die rekeningkundige } \\
\text { wins. }\end{array}$ & RE 102.85 (c) \\
\hline $\begin{array}{l}4.10 \text { 'n Verduideliking oor 'n verandering in die relevante } \\
\text { belastingkoers in vergelyking met vorige jare moet verskaf } \\
\text { word, indien van toepassing. }\end{array}$ & RE 102.85 (d) \\
\hline
\end{tabular}




\section{Bibliografie}

Byrnes N. 2002. Five ways to avoid more Enrons, Business Week, February 2002.

Cilliers, H.S., Mans, K.N., Grobbelaar, A.F., Stegman, N., Van Schalkwyk, J. and Wesson, N. 1999. Korporatiewe finansiële verslagdoening, Butterworths, Durban.

Everingham, G.K. and Kana, S.P. 2000. Corporate Reporting, 6th edition, Juta, Landsdowne.

Fama, E. 1970. Efficient capital markets: a review of theory and empirical work, Journal of Finance, May 1970.

Faul, M.A., Pistorius, C.W.I., Van Vuuren, L.M. and De Beer, C.S. 1994. Rekeningkunde: 'n Inleiding, Butterworths, Durban.

Flynn, D., Koornhof, C. and Bezuidenhout, D. 1987. Fundamental Accounting. An Introduction Text for Tertiary Students, Juta, Cape Town.

Hasenfus, M. 2002. Markkapitalisasie: Natuurlik maak grootte saak, Finansies \& Tegniek, Maart 2002, pp.20-23.

Holthausen, R.W. and Leftwich, R.W. 1983. The economic consequences of accounting choice: implication of costly contracting and monitoring, Journal of Accounting and Economics.

King Committee on Corporate Governance 2002. King report on Corporate Governance for South Africa 2002, Institute of Directors.

Linn, Z.J. and Wang, L. 2001. Financial Disclosure and accounting harmonization: cases of three listed companies in China, Managerial Auditing Journal, 2001, p.263.

Littleton, A.C. and Zimmerman, V.K. 1962. Accounting Theory: Continuity and Change, Prentice Hall, New York.

Marlton J, 2001. "Accounting in a changing environmemt", http//www.pwcglobal.com/za/eng/insl-sol/publ (June 2001).

Maatskappywet 1973. Die Maatskappywet 61 van 1973, Staatsdrukker, Pretoria.

Pitt, H.L. 2002. Public Statement by SEC Chairman: "Regulation of the Accounting Profession",

http://www.sec.gov/news/speech/spch535 (February2002).

SAIGR, 2000. Circular 5/2000, Professional Pronouncements, Uitgereik deur die Suid Afrikaanse Instituut vir Geoktroïeerde Rekenmeesters, Mei 2000.

Standpunt RE 000. Raamwerk vir die opstel en aanbieding van finansiële state, 1990.

Standpunt RE 102. Inkomstebelasting, Hersien in Maart 1999.

Standpunt RE 303. Verantwoording van sekondêre belasting op maatskappye, Julie 1999. 
Steyn, A.G.W., Smit, C.F. and Du Toit, S.H.C. 1989. Moderne Statistiek vir die praktyk, 4de uitgawe, Van Schaik, Pretoria.

Watts, R. and Zimmerman, J. 1986. Positive accounting theory, Prentice Hall, Englewood Cliffs.

Wells, J.T. 2001. And nothing but the truth: Uncovering Fraudulent Disclosure, Journal of Accountancy, July 2001, p.47. 